\title{
Harmonization of higher education in Africa and Europe: Policy convergence at supranational level
}

\author{
Ayenachew Aseffa Woldegiyorgis* \\ doi: http://dx.doi.org/10.18543/tjhe-5(2)-2018pp133-157
}

Received: 06.03.2018

Accepted: 04.05.2018

\begin{abstract}
While the Bologna Process in Europe is the leading example, regional efforts towards harmonization of higher education are taking place in every corner of the world. In Africa, such a process has its roots from decades ago, although more coordinated activities are only recent phenomena. This paper looks back at the harmonization processes in Africa and Europe, and argues that although the process in Africa has been influenced by its European counterpart, the former has its own unique features, among other things, in its thematic and sub-regional initiatives. The paper notes similarities and differences between the two processes, appreciates the strengths and shortcomings of the African process, and highlights the importance for the African Union to more effectively utilize its leverage as a coordinating body, with a wider and more meaningful involvement of higher education institutions and other stakeholders. It also calls for more exploration into the potential strengths and risks in harmonization initiatives strongly rooted at sub-regional level.
\end{abstract}

Keywords: Higher Education; harmonization; Bologna Process; regional integration, African Union.

\section{Introduction}

In the past couple of decades, one of the major developments in the global higher education landscape is the growing role of supranational organizations. As a result, phrases such as regionalization, harmonization, tuning, credit transfer, and mutual recognition of qualifications have become

* Ayenachew A. Woldegiyorgis (ayenachew@gmail.com) is a research assistant and doctoral student at the Center for International Higher Education (CIHE), Boston College (USA).

More information about the author is available at the end of this article (after the bibliography list). 
common in the vocabulary of higher education policy discussions in different parts of the world. New agreements, conventions, partnerships, networks, coordinations, and revitalization and/or reframing of the higher education role of regional organizations are constantly taking place.

While it is not possible to ignore the possibility of locally growing convergence in higher education policies, there seems to be a more recognizable trend that regions and supra-national organs learn from, and influence the practices of, one another. In this regard, the influence of the European Bologna Process is enormous. Initiated in 1999, the Bologna Process not only covered 48 countries in the European Union and beyond, but also the tenets of its policy ideas and methods of reform have diffused to different regions and inspired similar initiatives. ${ }^{1,2}$ The Bologna Process is generally one of the most influential policy reforms in Europe with significant contributions to the formation of a more coherent higher education and research area in the continent. ${ }^{3,4}$

In Africa, the last decade has seen a number of regional and sub-regional initiatives geared toward harmonization of higher education systems in the continent. This process has been accelerated not only by the growing engagement of the African Union, but also by the direct and indirect influence of the European Union and its initiatives - besides, of course, the impact of the Bologna Process. Hence, there are observably growing similarities between the higher education harmonization efforts in Europe and Africa.

This paper, using the concepts of policy convergence/transfer as theoretical framework, attempts to explain this growing similarity in the higher education harmonization initiatives in the two continents. More specifically, it looks at harmonization initiatives in the two continents, with a historical spectacle, and compares the two in terms of rationales, policy goals, organizational settings, components, and so on. The paper finally

${ }^{1}$ David Crosier and Teodora Parveva, The Bologna Process: Its Impact in Europe and beyond (Paris: UNESCO, International Institute for Educational Planning, 2013).

${ }^{2}$ Emnet Tadesse Woldegiorgis, "Historical and Political Perspectives: On Regionalization of African Higher Education," in Regionalization of African Higher Education:Progress and Prospects, ed. Jane Knight and Emnet Tadesse Woldegiorgis (Rotterdam, Boston, Taipei: Sense Publishers, 2017).

${ }^{3}$ Hans De Wit, "European Integration in Higher Education: The Bologna Process Towards a European Higher Education Area," in International Handbook of Higher Education, ed. James. J.F. Forest and Philip. G. Altbach (Dordrecht: Springer, 2007).

${ }^{4}$ Emnet Tadesse Woldegiorgis, "Conceptualizing Harmonization of Higher Education Systems : The Application of Regional Integration Theories on Higher Education Studies," Higher Education Studies 3, no. 2 (2013), https://doi.org/10.5539/hes.v3n2p12. 
draws some conclusions regarding the similarities and differences between harmonization of higher education in the two continents under consideration.

\section{Policy convergence: setting a conceptual frame}

The debate about whether higher education policy is going in the direction of convergence or divergence has been around for some time. The earlier implies the growing similarity in the policy goals and instruments of implementation across different systems, while the later suggests differences and growing diversification in policy formation and practice. ${ }^{5}$ Elaborating on these competing lines of thought, situated within the broader context of impact of globalization, Vaira ${ }^{6}$ noted that convergence stresses on the trend of homogenization in cultural, political and economic spheres and is based on "top-down and sometimes deterministic causal explanation". Divergence, on the contrary, emphasizes heterogeneity in the outcomes of globalization on the local level (national, regional and even organizational). Thus, it assumes non-linear and non-deterministic explanations which accord greater importance to "bottom-up processes of manipulation, localization, interpretation, mediation, resistance and so on".

Policy convergence according to Drezner ${ }^{7}$ is the tendency that policies grow more alike over time, in the form of increasing similarity in structures, processes, and performances. This generally happens because of overall similarities between societies through industrialization and modernization. Policy convergence happens as modern societies face similar problems and tend to solve them in similar ways. ${ }^{8}$ The ability of ideas to permeate across national boundaries has, indeed, a long history, but it is discernable how it has recently been accelerated by the advancement of communication technologies. Hence, it can be argued that convergence, more than divergence, is likely to have increased in recent decades, and is likely to keep increasing in the foreseeable future.

${ }^{5}$ Pam Watson, "Regional Themes and Global Means in Supra-National Higher Education Policy," Higher Education 58, no. 3 (2009), https://doi.org/10.1007/s10734-009-9203-3.

${ }^{6}$ Massimiliano Vaira, "Globalization and Higher Education Organizational Change: A Framework for Analysis.” Higher Education 48, no. 4 (2004), 484.

7 Daniel W. Drezner, "Globalization and Policy Convergence," International Studies Review 3, no. 1 (2001): 53-78, https://doi.org/10.1111/1521-9488.00225.

${ }^{8}$ Colin J. Bennett, "What Is Policy Convergence and What Causes It?" British Journal of Political Science 21, no. 2 (1991). 
Different theories can be used to explain the growing similarities in higher education policies. The World Society Theory ${ }^{9}$ suggests that the increasing similarities across societies are attributable to the views that advocate conformity to the dominant, legitimate, or taken-for-granted. Conventional ideas, for instance about higher education, can be seen as molds or blueprints that provide the framework to define what is 'normal' or 'appropriate'. The Resource Dependency Theory, on the other hand, associates growing similarities with coping mechanism and the need for survival. The one with less resource control (it could be an individual, organization or a system) is likely to accept the rules of, and to imitate the behavior of the one that has control over desired resources. ${ }^{10}$ This theory, however, has an implication of a unidirectional relationship between developing and developed regions which correspond with resource control. As Africa is considerably dependent on resources from the West, or in this case Europe, in the form of aid and loan, it is more likely to be driven by policy goals and processes coming from, or at least favored by, the latter.

Yet another alternative to explain this phenomenon is to employ the concept of policy transfer. ${ }^{11}$ Policy transfer can be conceptualized as the process of emulating elements of policy (such as policy goals, administrative arrangements, and/or institutions) of one time and/or place in the policy making process at another time and/or place. This process is likely a result of complex interactions between multiple actors in the respective systems, and could take place with different scopes - from general ideological orientation to routine practices. In their model of 'policy transfer continuum', Dolowitz and Marsh ${ }^{12}$ outline that policy transfer could possibly occur anywhere between 'lesson drawing' on one extreme where the receiving system takes a rational approach to decide the elements

9 John. W. Meyer et al., "The Structuring of a World Environmental Regime, 18701990." International Organization 51, no. 4 (1997), https://scholar.google.com/ scholar?hl=en\&as_sdt=0\%2C22\&q=The $\% 21+$ structuring $\% 21+$ of $\% 21+\mathrm{a} \% 21$ world $\% 21+$ envi ronmental\%21+regime\&btnG $=$.

${ }^{10}$ Werner Nienhüser, "Resource Dependence Theory - How Well Does It Explain Behavior of Organizations?" Management Review 19, no. 1\&2 (2008): 9-32, https://doi. org/10.5771/0935-9915-2017-2-192.

${ }^{11}$ David Dolowitz, and David Marsh, "Who Learns What from Whom: A Review of the Policy Transfer Literature," Political Studies 44, no. 2 (June 29, 1996), https://doi. org/10.1111/j.1467-9248.1996.tb00334.x.

${ }_{12}$ David Dolowitz, and David Marsh, "Learning from Abroad: The Role of Policy Transfer in Contemporary Policy-Making," Governance 13, no. 1 (January 2000), https://doi. org/10.1111/0952-1895.00121. 
and methods of adoption that are most beneficial, to 'coercive transfer' on the other end - where policy is directly imposed by one system on the other.

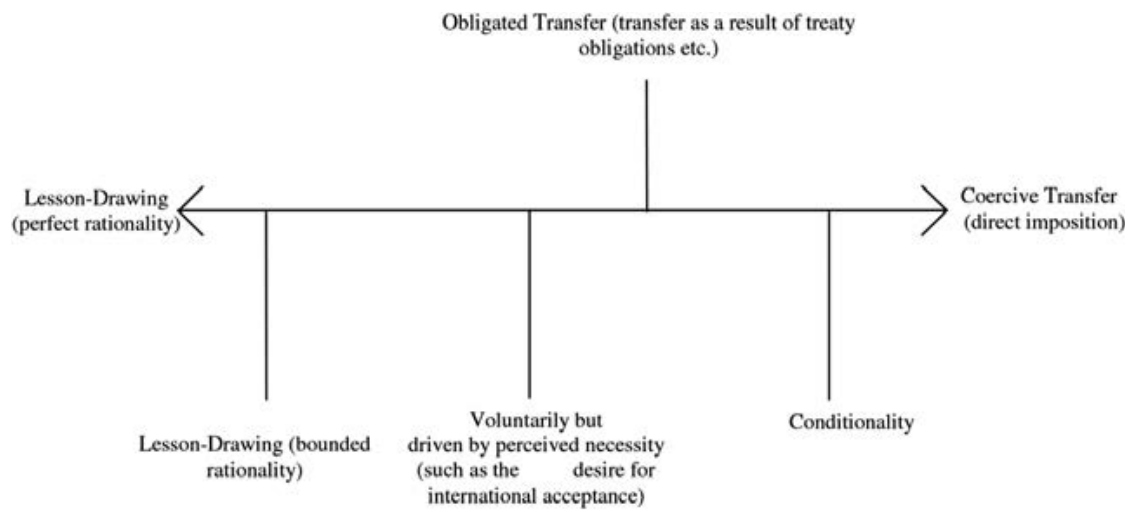

Source: Dolowitz and Marsh, 2000, p. 13.

While policy transfer takes a broader view at a system level, institutional isomorphism, as an alternative, focuses more on the change that takes place at institutional level. This theory suggests that institutions tend to grow similar to one another as a result of the continuous change they undergo to respond to shift in their environment; and that the internal change takes place in three different forms: coercive, mimetic and normative. ${ }^{13}$ Coercive implies changes that are imposed or enforced by external body, while mimetic presumes the willingness of institutions to mimic others in similar business, and normative changes happen in gradual and complex process where institutions look elsewhere to see and learn from the norm. There are similarities in the concepts of policy transfer and institutional isomorphism, albeit their varying units of analysis. Also, both appear to fall short to explain a phenomenon that is happening at regional level and where a supranational organ is the major actor.

Lastly, it is important to underscore that as much as the theories highlighted above are useful in explaining policy convergence in higher education, they are limited in their consideration of local factors as drivers of

${ }^{13}$ Paul J. DiMaggio and Walter W. Powell, "The Iron Cage Revisited: Institutional Isomorphism and Collective Rationality in Organizational Fields," American Sociological Review 48, no. 2 (1983), https://doi.org/10.1016/S0742-3322(00)17011-1. 
change. As proponents of the policy divergence thesis hold, varying local conditions enable and force actors to interpret global developments in different ways and respond with nuances pertinent to their own circumstances. The implication of this argument is that policy convergence should not be taken synonymous with uniformity of policy.

There are scholars who, in an attempt to find a middle ground for the convergence-divergence dichotomous debate, articulate tiers of forces that contribute to changes in local policies and institutions. Marginson and Rhoades,${ }^{14}$ for instance, proposed a glonacal agency heuristic which stresses the roles of global, national and local agencies in comparative higher education policy analysis. Similarly, Vaira ${ }^{15}$ introduced a concept called "organizational allomorphism", which acknowledges the existence of multiple actors at different levels that exert force on organizational change. The micro level actors enable organizations to respond differently to global forces.

\section{Policy harmonization and emergence of supranational organs}

Policy harmonization and regional integration have emerged as major subjects of discussion since the end of the Second World War. According to Cini, ${ }^{16}$ in the post war world a new notion of political structure started taking shape, which, at its core questioned the legitimacy of the traditional structure that gave absolute dominion of policy formulation and implementation for the nation-state. In the following decades, the growing power of globalization, or more specifically, as Vaira ${ }^{17}$ calls it, the "globalization meta-myth" has pushed for the realization of this newly emerging global political structure. The myth has three major features that can be directly related with this development in higher education. ${ }^{18}$

(a) Minimalist state: this feature represents the trend in the reduction of the level of centralization of power in the state and its interventionist role, in favor of decentralized and less bureaucratized system where

${ }^{14}$ Simon Marginson and Gary Rhoades, "Beyond National States, Markets and Systems of Higher Education: A Glonacal Agency Heuristic," Higher Education 43, no. 3 (2002).

15 Vaira, "Globalization and Higher Education."

${ }^{16}$ Michael Cini, "Intergovernmentalism," in European Union Politics, ed. Michael Cini, 93-108 (Oxford: Oxford University Press, 2003).

17 Vaira, "Globalization and Higher Education," 487.

18 Ibid., 487-488. 
the state is more of regulative body. With reducing state funding, government uses steering at distance and with broader policy instruments, focusing more on evaluation of performance and outcomes, than on the routine process.

(b) Entrepreneurialization/managerialization: this goes hand in hand with the minimalist state. As public funding was reduced, a trend towards a more entrepreneurial and managerial mode of organizational operation emerged. The coming-in of such concepts from the business world to higher education marks this shift: flexibility, innovation and quality in production and products to meet customer demands.

(c) Knowledge society: the advancement of technology and the growth in competitiveness in the global economy led to the emphasis on knowledge production and information processing for better competitive advantage. The shift from labor intensive manual workers as the engines of production to the flexible knowledge workers pumped the role of higher education in human capital development. Therefore, higher education institutions gained more power as drivers of economic development.

The concepts are largely promoted by, and in return gave more legitimacy to international organizations such as UNESCO, the World Bank, IMF, and the OECD. Sehoole and de $\mathrm{Wit}^{19}$ also point to the importance of regional trade and economic cooperation, such as the North American Free Trade Agreement (NAFTA), the Asia Pacific Economic Cooperation (APEC), Mercado Comun del Sur (MERCOSUR), the Association of South East Asian Nations (ASEAN), in policy diffusion and harmonization. All in all, in addition to the enormous power of international organizations, the growth of multinational corporations, the growing interest of countries to attract foreign direct investment leading to the free flow of capital, and the growing power of unaccountable market forces slowly diluted the sovereignty of the state in policy making. ${ }^{20}$ This, in turn, led to the formation and strengthening of supranational policy actors playing an increasingly important role in higher education policy reform.

${ }^{19}$ Chika Sehoole and Hans de Wit, "The Regionalisation, Internationalisation, and Globalisation of African Higher Education," International Journal of African Higher Education 1, no. 1 (2014), https://doi.org/http://dx.doi.org/10.6017/ijahe.v1i1.5648.

${ }^{20}$ Woldegiorgis, "Conceptualizing Harmonization of Higher Education Systems." 


\section{Harmonization of higher education in Europe}

Neave ${ }^{21}$ traces the beginning of higher education harmonization in Europe to the European Education Action Program, which began in 1976. Several other agreements were signed in the following years building up to the regional integration of higher education in Europe. The prominent agreements include the Bologna Magna Charta Universitatum in 1988 and the Sorbonne Declaration of 1998, which ultimately culminated by the signing of the Bologna Declaration in 1999.22 The number of countries participating has increased from just four signatories to the Sorbonne Declaration to 29 at the signing of the Bologna Declaration in 1999, and 48 countries currently, along with the European Commission, according to the website of the European Higher Education Area [EHEA]. ${ }^{23}$

Sorbonne Declaration, an important precursor to the Bologna Declaration, was signed by education ministers representing France, Germany, Italy, and the United Kingdom. The declaration laid down the important steps needed to be taken towards creating an open European area of higher learning. It focused on making European higher education internationally attractive and comparable by way of creating common qualification framework and making degree structures common across countries. It also underscored the importance of student mobility and the need to align degree programs with the European labor market. ${ }^{24}$

The following year came the Bologna Declaration, marking the beginning of an unprecedented process of harmonization. Crosier and Parveva ${ }^{25}$ note that these developments coming at that specific time is not a mere coincidence. They identify two major forces traceable to the drive for harmonization.

- In the last decades of the $20^{\text {th }}$ century, there was a considerable increase in the number of student population, in most European countries. This created a strong demand for the higher education systems to expand and also to respond to new social demands.

${ }^{21}$ Guy Neave, "The Bologna Declaration: Some of the Historic Dilemmas Posed by the Reconstruction of the Community in Europe's Systems of Higher Education," Educational Policy 17, no. 1 (January 25, 2003), https://doi.org/10.1177/0895904802239290.

22 Crosier and Parveva, The Bologna Process.

${ }^{23}$ European Higher Education Area [EHEA], "Members - European Higher Education Area and Bologna Process,” 2017, https://www .ehea.info/pid34250/members.html.

${ }^{24}$ Sorbonne Declaration, "Sorbonne Joint Declaration. Joint Declaration on Harmonization of the Architecture of The European Higher Education System," 1998, http://media.ehea.info/ file/1998_Sorbonne/61/2/1998_Sorbonne_Declaration_English_552612.pdf.

${ }^{25}$ Crosier and Parveva, The Bologna Process. 
- Knowledge-based economy emerged as a mainstream rhetoric in the political discourse as the only path to competitiveness in the world of accelerating globalization. Knowledge based economy not only brought higher education to center stage as a policy domain by underscoring the importance of human capital, but also called for the easy cross-border movement of skills in the labor market. This is further legitimized within the EU, with the coming of the Lisbon Strategy, in 2000, which targeted on promoting Europe as the most competitive and dynamic knowledge-based economy in the world.

The realization of these forces demanded that countries needed to make far reaching reforms in their higher education systems to ensure competitiveness as well as comparability. This could, perhaps, explain what attracted much more countries to participate in the Bologna Declaration jumping from only four to 29 signatories in just a year. This was reflected in the declaration's intension of making European higher education more compatible and comparable, more competitive and attractive, not only for students and scholars form with in Europe but also globally.

The Bologna Declaration, with the ultimate goal of creating European Higher Education Area (EHEA), reiterated the main focus points of the Sorbonne Declaration. The signatories outlined the following six areas of emphasis. ${ }^{26}$

(a) The adoption of easily readable and comparable degrees, along with the implementation of Diploma Supplement

(b) The adoption of a system based essentially on two main cycles undergraduate and graduate

(c) The establishment of a system of credits (such as ECTS),

(d) Supporting the mobility of students, teachers, researchers, and administrative staff, by overcoming obstacles to free movement

(e) Promoting European cooperation in quality assurance with a view to developing comparable criteria and methodologies

(f) Promoting the European dimensions in higher education particularly with regards to curricular development, inter-institutional co-operation,

${ }^{26}$ Bologna Declaration, "The Bologna Declaration of 19 June 1999. Joint Declaration of the European Ministers of Education,” 1999, http://media.ehea.info/file/Ministerial_ conferences/02/8/1999_Bologna_Declaration_English_553028.pdf. 
mobility schemes and integrated programs of study, training and research.

The Bologna Declaration marked the beginning of the Bologna Process. It is set up as a process such that there would be follow-up ministerial meetings every two years to assess the progress made and to determine further steps needed to be taken. While the consecutive ministerial meetings reaffirmed the original goals of the Declaration, there have been incorporations of new dimensions (of course also the admission of new countries). The Prague meeting in 2001 reemphasized the importance of lifelong learning and the need for partnership with higher education institutions. ${ }^{27}$ It also established the Bologna Follow-up Group (BFUG), composed of representatives of all signatory countries, the European Commission, and key stakeholder organizations, and charged with overseeing the continued development of the process. ${ }^{28}$

Another important development came with the Berlin meeting in 2003, where the cultural benefits of higher education were emphasized, and higher education was once again reaffirmed as a public good. The need for regional qualification framework and quality assurance principles were also among the major issues discussed in this meeting..$^{29}$ In the Bergen meeting in 2005, the Standards and Guidelines for Quality Assurance in the European Higher Education Area (ESG) and the Framework of Qualifications for the European Higher Education Area (FQ-EHEA) were adopted.

In 2007 the London meeting established the European Quality Assurance Register (EQAR), which registers quality assurance agencies that comply with the standards and guidelines in the ESG. Also in this meeting the ministers agreed to develop national strategies emphasizing social dimensions and a collective strategy for the global dimension of the European higher education. ${ }^{30}$ The Leuven/Louvain-la-Neuve meeting of 2009 looked back and assessed the positive achievements made in the last ten years - better compatibility and comparability through structural changes and implementation of ECTS and Diploma Supplement. Nonetheless, acknowledging that the EHEA has not yet been fully realized, the ministers also agreed to set strategic priorities for another decade, until 2020.

\footnotetext{
27 Watson, "Regional Themes and Global Means."

${ }^{28}$ Crosier and Parveva, The Bologna Process.

29 Watson, "Regional Themes and Global Means."

${ }^{30}$ Crosier and Parveva, The Bologna Process.
} 


\section{Harmonization of higher education in Africa}

Referring to the regionalization of higher education in Africa, Woldegiorgis ${ }^{31}$ notes that integration in higher education should not be seen as an independent process; instead it has to be situated with in the broader political and economic initiatives and developments in the region. Hence, the history of regional collaboration on various policy issues goes as far back as the 1950s with the emergence of several African countries from colonization. The newly independent states were internally weak, with illegitimate institutions inherited from their colonizers, and inefficient to represent Africa on the global stage. At the same time, there was a sense of solidarity with those countries still under colonial control, leading to the rise of African Nationalism and Pan-African movement among the elites. With these precursors, the first Pan-African conference was convened in April 1958, in Accra, Ghana, with eight independent states with the objective of establishing a regional body that could serve as a forum for regional policy dialogue. ${ }^{32} \mathrm{~A}$ series of meetings in the following period ultimately led to the establishment of the Organization for African Unity (OAU), in 1963, which, among other things, targets on strengthening unity and solidarity among African states, and promoting political and socioeconomic coopration among them.

In the post independence era, African intellectuals and political elites, like the Tanzanian leader and a prominent Pan-Africanist Julius Nyerere, advocated for education as the only means to emancipate the continent from its multifaceted predicaments. ${ }^{33}$ Countries established and strengthened their higher education institutions, although the colonial model was adopted as a wholesome. The establishment of the Association of African Universities (AAU) and the strong enthusiasm with it regarding the expectation of higher education in the transformation of the continent was enormous. $^{34}$

31 Woldegiorgis, "Historical and Political Perspectives."

32 Woldegiorgis, "Historical and Political Perspectives."

33 Joel Samoff and Bidemi Carrol, "The Promise of Partnership and Continuities of Dependence: External Support to Higher Education in Africa," African Studies Review 47, no. 1 (2004), https://scholar.google.com/scholar?hl=en\&as_sdt=0\%2C22\&q=The+Promise+of+P artnership+and+Continuities+of+Dependence $\% 3 \mathrm{~A}+$ External+Support+to+Higher+Education + in + Africa $\&$ btnG $=$.

${ }^{34}$ Y. G. M. Lulat, "The Development of Higher Education in Africa: A Historical Survey," in African Higher Education: An International Reference Handbook, ed. Damtew Teferra and Philip G. Altbach (Bloomington: Indiana University Press, 2003). 
In the 1960s and 1970s, African ministers of education, in collaboration with regional organizations such as OAU, AAU, United Nations Economic Comission for Africa (UNECA) and UNESCO, had organized consequitive conferences focused on the development of regional plan for the future of education. Intergovernmental conferences of Ministers of Education of African Member States were held in Addis Ababa (1961), Abidjan (1964), Nairobi (1968), Lagos (1976). Indeed, in these conferences higher education was not the exclusive subject of discussion, but it was part of the agenda. ${ }^{35}$ These meetings, however, are important in their contributions leading up to the seminal meeting in Arusha in December 1981.

Continental harmonization of higher education in Africa has its roots back in the early 1980s with the signing of the Arusha Convention. This is the first prominent legal framework established at continental level towards mutual recognition of degrees and qualifications in higher education. Originally ratified by 19 countries and set to take effect in 1983, the Convention was meant to contribute to UNESCO's initiative to promote international mobility and to support the implementation of the charters of Organization of African Unity (OAU) especially in regional co-operation and training of human resources. It was also meant to promote the creation and application of knowledge towards sustainable human development. ${ }^{36}$ Signatories also agreed to improve collaboration and sharing of resources and to cooperate in curriculum development, promoting lifelong learning and democratization of education. ${ }^{37}$ However, although ratified by the required number of Member States of the the OAU, the Convention was never implemented. ${ }^{38}$

In 1982, one year after the Arusha convention, another conference of ministers of education was held in Harare, Zimbabwe. This conference largely focused on regional cooperation in the area of higher education, specifically in science and technology which was generally evaluated to be very low. ${ }^{39}$ However, the following years were dormant for regional initiatives in higher education in the continent. This can be seen in light of the overall decline of higher education in Africa during that period, as the policies of the

35 Woldegiorgis, "Historical and Political Perspectives."

${ }^{36}$ Karola Hahn and Damtew Teferra, "Tuning as Instrument of Systematic Higher Education Reform and Quality Enhancement : The African Experience," Tuning Journal for Higher Education 1, no. 1 (2013), http://www.tuningjournal.org/public/site/01/7_Tuning_as_ Instrument_of_Systematic_Higher_Education_Reform_and_Quality_Enhancement.pdf.

37 Watson, "Regional Themes and Global Means."

${ }_{38}$ Hahn and Teferra, "Tuning as Instrument."

39 Woldegiorgis, "Historical and Political Perspectives." 
World Bank dictated countries otherwise. ${ }^{40}$ Woldegiorgis,${ }^{41}$ however, attributes the lack of implementation of the Arusha convention to the fact that it is set in general terms and specific modalities, strategies and procedures for execution among African countries had not been harmonized. Even though these instruments were clarified, it is difficult to see that such an initiative in higher education is being implemented - getting required attention and resource in overall gvernment policies - considering that the period was generally unfavorable for the development of higher education in the continent.

The Arusha Convention was reinitiated right after the turn of the century. It was ammended first in 2002 in Cape Town, followed by several others which finally resulted in a more comprehensive revision in Addis Ababa in 2014 (also referred to as the Addis Convention). This revived interest in higher edication can be attributed to three factors. First, there was a change of policy by the World Bank encouraging African Nations to invest more in higher education. As the Bank is a major actor in the continent not only in the amount of resources it provides but also in the level of influence it has over the direction of other donors ${ }^{42}$ the change of heart by the Bank was a major shift. Second, the reorganization of OAU into African Union (AU), which more or less was an immitation of the EU ${ }^{43}$ had a more diverse and dynamic focus on various issues of socio economic policy. Besides, since higher education was one of the major areas of policy focus in the EU, it is likely to be replicated by the AU. Third, an overall paradigm shift that put higher education at the center of the continental development strategy had started in the first decade of the $21^{\text {st }}$ century. This shift, according to Hahn and Teferra ${ }^{44}$ has been instrumental in the revitalization of higher education across the continent, driven by national, regional and international imperatives.

The process of higher education harmonization in Africa is happening far more intensely at sub-continental level than at the continental level. Therefore,

40 Stephen P. Heyneman, "The History and Problems in the Making of Education Policy at the World Bank, 1960-2000," International Journal of Educational Development 23, no. 3 (2003): 315-37, https://doi.org/10.1016/S1479-3679(04)06002-5.

${ }^{41}$ Woldegiorgis, "Historical and Political Perspectives."

${ }^{42}$ Ayenachew A. Woldegiyorgis, "The Indelible Footmarks of the World Bank in the Higher Education of the Developing World : The Case of Ethiopia," International Journal of Research Studies in Education 3, no. 3 (2014): 93-106.

43 Amadu Sesay, "The African Union: Forward March or About Face-Turn?" Claude Ake Memorial Papers, 2008, http://nai.diva-portal.org/smash/get/diva2:278874/FULLTEXT01.pdf

${ }^{44}$ Hahn and Teferra, "Tuning as Instrument." 
understanding this process requires the context of these regional initiatives towards harmonization and integration. Hahn and Teferra ${ }^{45}$ have identified the following sub-regional initiatives, most of which are extensions of subregional cooperations in economic, political and other areas of relevance.

i. Southern African Development Community (SADC): The Protocol on Education and Training (1997), aims at achieving equivalence, harmonization and, in the long term, standardization of higher education in the sub-continent. Ratified by all member states except three (Angola, DR Congo and Seychelles), it came into force in 2000. Two articles $(7 \& 8)$ of the Protocol specifically refer to higher education and training cooperation, and identifies key areas of harmonization.

ii. East African Community (EAC): East African Common Market Protocol was signed by five countries in 2009. In Article 11, the protocol addresses issues related to mutual recognition of qualifications, and harmonization of curricula, examination, standards, certification and accreditation of institutions to promote free movment of labor in the region. Prior to this protocol, regulatory bodies for higher education of three countries (Kenya, Uganda and Tanzania) signed a memorandum of cooperation in 2006, which outlined their common areas of concern. This agreement ultimately led to the establishment of the Inter-University Council for East Africa (IUCEA).

iii. Economic Community of West African States (ECOWAS): Protocol on Education and Training and General Convention on the Recognition and Equivalence of Degrees, Diplomas, Certificates and Other Qualifications was the basis to the region's education policy developed in 2002. The convention focused on promoting recognition of qualification, skills exchange and reducing braindrain. Regional integration and harmonization is also part of the ECOWAS Vision 2020, signed in 2008 .

iv. Association of Arab Universities (AArU): Founded in 1964 and working within the general framework of the Arab League, AArU is undertaking harmonization initiatives. However, unlike the other sub-continental initiatives, AArU is not limited ot the Arab states in North Africa; it covers the entire Arab region. Another geographically

45 Ibid., 130-134. 
similar initiative is the Arab Network for Quality Assurance in Higher Education (ANQAHE), established in 2007. The network has national quality assurance agencies as members, and works in different areas related to quality, and development of a regional qualification framework (Arab Generic Qualification Framework).

v. African and Malagasy Council for Higher Education (Conseil Africain et Malgache pour l'Enseignement Supérieur [CAMES]): CAMES covers the Francophone Africa. Established in 1968, CAMES works for the alignment of programs in member states. Since 2005, it is more specifically focused on the harmonization of seven Francophone degrees to to the "Licence-Master-Doctorat" (LMD) format, which is in line with the Bologna process.

The most recent efforts in coordinated continental higher education harmonization begins with the adoption of the Second Decade of Education for Africa (2006-2015) by AU member states. This document outlined principles and goals that recognize the need and importance of harmonization (though not specific for higher education). "Concentration on strategic issues whose implementation will make a significant difference at member state and regional levels" 46 is one of the guiding principles.

The following year a landmark strategic document "Harmonization of Higher Education Programmes in Africa: A Strategy for the African Union" was issued which provided general direction for improving capacity and quality in higher education at continental level. As quoted in Watson ${ }^{47}$ the document stated that harmonization of higher education will:

facilitate the comparability of qualifications awarded across the continent and help drive quality assurance measures which will ultimately contribute to greater quality of education in Africa. Creating a mechanism for benchmarking and comparison of qualifications will allow for professional mobility for employment and further study, as well as expanded job markets. Developing widely accepted standards for quality will also facilitate creation of centres of excellence. Harmonisation will benefit Africa, since it will allow for greater intra-regional mobility, thereby fostering increased sharing of information, intellectual resources, and research, as well as a growing ability to rely on African expertise rather than skills from elsewhere in the world.

${ }^{46}$ African Union, "Second Decade of Education for Africa (2006-2015): Draft Plan of Action," 2006, 2, http://www.adea-comed.org/version2/IMG/pdf/SECOND_DECADE_OF_ EDUCATION_FOR.pdf.

${ }^{47}$ Watson, "Regional Themes and Global Means." 
The production of human resources that have the competencies required for driving Africa's economic and social development is the overarching developmental objective of the strategy. More specifically the major goals include: ${ }^{48}$

- Revision and ratification of the Arusha Convention

- Creation of a central database of African higher education institutions (HEIs) and programmes.

- Establishment of an African system to measure performance of HEIs.

- Development of a continental framework for qualifications.

- Promotion of mechanisms for Quality Assurance at national levels, operating within agreed minimum standards at regional and continental levels.

- Promotion of open, distance and technology-mediated learning and the use of Open Education Resources.

Major initiatives, perhaps consequential to the harmonization strategy, have been launched, including: intera-Africa mobility (Nyerere Program), Tuning Africa, regional qualification frameworks, and African Quality Rating Mechanism. 49,50,51,52 Harmonization also emerged as one of the major priority areas in the Africa-EU strategic partnership..$^{53}$

\section{Comparison of the two processes}

The overarching goals of the two hrmonizaition initiatives show, as one might expect, strong similarities. At the center of both is the production of

${ }^{48}$ Goolam Mohamedbhai, "Towards an African Higher Education and Research Space (AHERS) - A Summary Report,” 2013, http://www.adeanet.org/en/system/files/resources/ ahers_summary_report.pdf.

${ }^{49}$ Hahn and Teferra, "Tuning as Instrument."

${ }^{50}$ Mohamedbhai, "Towards an African Higher Education and Research Space (AHERS)."

${ }^{51}$ Charles Awono Onana et al., Tuning and Harmonisation of Higher Education: The African Experience (Bilbao: University of Deusto, 2014).

${ }^{52}$ Olusola Oyewole, "The African Quality Rating Mechanisms: The Process, Prospects, and Risks," in Fourth International Conference on Quality Assurance in Higher Education in Africa and Capacity Building, (Bamako, 2010), http://ifgu.auf.org/media/document/ KEYNOTE_Oye_AQRM_Process-Prospect_and_Risks_2.pdf.

53 African Union and European Union, "Joint Africa EU Strategy Action Plan 2011-2013," 2011, http://www.africa-eu-partnership.org/sites/default/files/documents /03-jeas_action_plan_ en.pdf. 
required skills for the respective continents, focusing on the readability and compatability of higher education programs and qualifications to allow free movement of human capital. Both policy settings not only recognize the importance of harmonization for improving quality of education, but also use the same rationales of chaning circumstances in economy and in higher education necessitating the process. It has to be noted, however, that the economic circumstances in the two continents are quite different, although they both operate in a growingly competitive and knowledge driven global economy.

In terms of expected targets, the harmonization process in Europe had it clear: to create the European Higher Educaiton Area by 2010. Upon evaluation of achievments and limitations, a new target is set for 2020, along with other initiatives embedded in the European Union..$^{54}$ The African counterpart, although not as clearly stipulated, eyes on the creation of African Higher Education and Research Space (AHERS).$^{55}$ This similarity in policy goals can be understood as a result of the natural process of policy convergence in higher education that is being seen not only in these two regions but also elsewhere. Notwithstanding the fact that the Bologna Process has diffused into regional initatives in different parts of the world, one can observe that the erlier harmonzation initiative in Africa, i.e. the Arusha Convention, which came far before the Bologna Declaration, has similar essence.

Nonetheless, this is not to mean that the African harmonization process has not learned from its European counterpart. Indeed, one can argue that the harmonization process in Africa is largely influenced by the one in Europe in many ways.

- The influence of the Bologna Process on similar initiaives of other regions is well documented. ${ }^{56}$ The process has produced a substantial volume of knowledge and coherent rethoric about the whole experience that it sets 'the norm' for other regions pursuing similar initiatives.

- Not only that scholars were calling upon the AU to adopt a Bologna-like process, AU comissioned studies and reports also reflected on the Bologna Process and its relevance to Africa. ${ }^{57,58}$ The ease in benchmarking

${ }^{54}$ Crosierand Parveva, The Bologna Process.

${ }_{55}$ Mohamedbhai, "Towards an African Higher Education and Research Space (AHERS)."

${ }_{56}$ Crosier and Parveva, The Bologna Process.

${ }^{57}$ Mohamedbhai, "Towards an African Higher Education and Research Space (AHERS."

${ }^{58}$ Hamidou Nacuzon Sall and Baye Daraw Ndjaye, "Higher Education in Africa: Between Perspectives Opened by the Bologna Process and the Commodification of Education," European Education 39, no. 4 (2007), https://doi.org/10.2753/EUE1056-4934390403. 
the rich experience of a longstanding and strong partner, the EU,,$^{59}$ seemed a reasonable direction to follow.

- Besides the fact that AU has immitated the EU in (too) many ways ${ }^{60}$ and that this is likely to include the different policy goals and initiatives, EU has been a major partner of AU since its inception. Through the Africa-EU strategic partnership and other initiatives, EU not only heavily finances projects but is also involved in the process through its techical assistance. ${ }^{61,62,63,64,65}$

- The ideals of the Bologna Process also premeate through North-South institutional, bilateral and multilateral cooperations. Countries which are members to the Bologna process, and have reformed their higher education system accordingly, are likely to push ideals (elements) of it through the partnership arrangements, to their partners in Africa. This could materialize through the development aid the European countries provide and the legacy of the colonial relationships, which remains instrumental in higher education. Sall and Ndjaye ${ }^{66}$ have noted that France, for instance, among other countries, has explicitly expressed its wish for its former colonies to adopt the Bologna process; Belgium has also conducted repeated conferences in the Great Lakes Regions, themed in line with the adjustment of African higher education to the Bologna Process.

- The use of tools that were developed/tested in the European process is another mechanism of influence. Tuning, one of the most instrumental

59 Olufemi Babarinde, "The EU as a Model for the African Union: The Limits of Imitation," The Jean Monnet/Robert Schuman Paper Series 7, no. 2 (2007), http://aei.pitt. edu/8185/1/Babarinde EUasModellong07edi.pdf.

${ }^{60}$ Sesay, "The African Union."

${ }^{61}$ African Union and European Union, "The Africa-EU Strategic Partnership: A Joint Africa-EU Strategy," 2007, http://www.africa-eu-partnership.org/sites/default/files/documents/ eas2007_joint_strategy_en.pdf.

62 African Union and European Union, "Joint Africa EU Strategy Action Plan 20112013," 2011, http://www.africa-eu-partnership.org/sites/default/files/documents/03-jeas_ action_plan_en.pdf.

${ }_{63}$ African Union and European Union, "Fourth EU-AFRICA Summit: Roadmap 20142017,” 2014, https://www.consilium.europa.eu/media/21520/142094.pdf.

${ }^{64}$ Emnet Tadesse Woldegiorgis, Petronella Jonck, and Anne Goujon, "Regional Higher Education Reform Initiatives in Africa: A Comparative Analysis with Bologna Process," International Journal of Higher Education 4, no. 1 (2015), https://doi.org/10.5430/ijhe.v4n1p241.

${ }^{65}$ Ibid.

${ }^{66}$ Sall and Ndjaye, "Higher Education in Africa." 
tools being emploiyed in the African harmonization process appears to have been borrowed from the Bologna process ${ }^{67}$. Similarly, the African harmonization process seeks a continent wide credit transfer system. In this regard, there have been calls for the launch of African Credit Accumulation and Transfer System ${ }^{68}$ a parallel of the European Credit Accumulation and Transfer System (ECTS).

Overall, strong similarities are observable in the harmonization processes of the two continents. This is evidenced, more than anything else, by the parallel in the major components of the two processes: student and staff mobility, comparability of degree programs, the creation of qualification frameworks, the establishment of regional quality assurance framework, etc.

This, however, should not preclude the acknowledgement of differences, in some cases nuances, between the two processes. There are some tools that remain unique to the respective systems, or have different versions. The African Higher Education Quality Rating Mechanism, for instance, is an instrument institutions can use to assess themselves within the context of what quality means for an African institution ${ }^{69}$ With a broad continental standards and principles in place, the European Quality Assurance Register (EQAR) keeps record of compliant quality assurance agencies. The Diploma Supplement, an instrument used in Europe to facilitaite comparability is not a component of the African counterpart process. However, since the harmonization process in Africa is at the early stage it is not possible to speculate if it will, or will not, continue to adopt from Europe.

Knowledge production and information sharing is another area of contrast. A stack of background studies, progress reports, country reports, communiques, along with uptodate website information and abundant availability of data in Europe, is in stark contrast with the situation in Africa. As of the writing of this paper (March 2018), for instance, one of the seminal documents, which, in 2007, introduced detail strategic plan for higher education harmonization in the continent - Harmonization of Higher Education Programmes in Africa: A Strategy for the African Union - is not avilable online. Although information sharing is stated as one of the major tasks necessary for harmonization, there is also no specific website dedicated to the initiative.

It would be fair to say that the Bologna process, compared to the counterpart in Africa, is far more organized, and evolved over the years as a

${ }^{67}$ Hahn and Teferra, "Tuning as Instrument."

${ }^{68}$ Mohamedbhai, "Towards an African Higher Education and Research Space (AHERS).,

${ }^{69}$ Oyewole, "The African Quality Rating Mechanisms." 
more comperhensive and coherent process. The follow up meetings every two years, with diverse stakeholders involved, and the incorporation of new agendas, and action plans, as well as respective consultative memebers, created a coordinated process under the purview of the the Bologna FollowUp Group (BFUG). The process in Africa can be characterized as rather thematic and sub-regional. There are initiatives which seem to be independently planned and implemented, althouth later brought in as integral components of the harmonization process (e.g. Pan-African University, Nyerere Mobility Program). On the other hand, strengths in the harmonization process are found in the regional initiatives. This being a positive approach in its own, there is a risk that the sub-continental initiatives might not be well coordinated and readable to one another. The strength of coordination, indeed, can be related to AU's resources dependence on expernal parties such as the EU. AU is way too resource dependent on external sources to chart its own comprhensive development trajectory and thus is influenced by the wills of dononrs. Differnet initiatives are desigened and implemented in fragmented manner, often donors being willing to fund on a case-by-case basis. However it is also discernible that the process lacks in clearly articulated long term goals and action plans, as well as framework of implemtnation, to which AU and other stakeholders need to be committed and mobilize resources accordingly.

\section{Conclusions}

There are several similarities in the policy goals, rationalizations and implementation processes of harmonization efforts in Africa and Europe. This observation conviniently leads to the conclusion that the African process is modeling itself after the European one, as postulated in the world society theory. It is indeed the case that the African harmonization process is considerably influenced by the one in Europe. This, among other things, predominantly speaks to the limitations of the African process, as explained by the resource dependency and policy transfer theories (and memetic processes in institutional isomorphism). Although the influence of the Bologna Process is enormous in Africa as it is elsewhere, there are also similarities in policy goals that predated the Bologna Declaration. The goals stipulated in the Arusha Convention nearly two decades before the Bologna Process are, in essence, very similar to those in the harmonization processes of both continents in the later years. This implies that there are naturally emerging policy convergences between the two continents. The remarkably 
similar rationales for the initiation of harmonization process speaks to Bennet's (1991) proposition that societies facing similar challenges tend to address them in similar ways.

There are also differences and nuances observed between the two processes. These differences, in line with the localized responses to global forces,$^{70,71}$ require more attention for further study. Much more is written about the similarities than about the unique features. The thematic nature of the African harmonization process and the strong structural orinentation in sub-continental processes deserve more exploration. It can be argued, for instance, that the sub-continental focus has strong merits since the participating countries have more in common anchored in their geographic proximity and shared history. In such arrangement, harmonization of higher education can fit in the broader context of cooperation and integration in terms of trade, ecomony, peace and security, and so on. However, it would also be reasonable to be cautious that if the subcontinental processes continue taking deeper roots, it can preclude the realization of continental harmonization. It could lead to the creation of sub-continental systems that have difficulties in reading and comparing each other.

For a continental system to emrge, therefore, there is a need to coordinate the existing efforts into a continent-wide system, while capitalizing on the strengths of the sub-continental initiatives. This can be viewed along with the advantage that AU has as a supranational coordinating body, which the EU did not enjoy with the Bologna Process, at least formally. One of the challenges to the Bologna Process in its initial days was that countries were resistant of any possible external influence, primarily from the EU, on their higher education policies. As a result, the EU had to remain hands-off of the Bologna Process, and use other mechanisms of soft influence- e.g. the EU created related programs that were linked to the reforms in the Bologna Process; it also used resources that were directly allocated for participating institutions, sidestepping the national policy making agencies. ${ }^{72}$ The AU, however, does not seem to have such a resistance. It has a central role more or less accepted by its member states. Its education programs, which include

${ }^{70}$ Marginson and Rhoades, "Beyond National States, Markets and Systems of Higher Education."

71 Vaira, "Globalization and Higher."

72 Agnes Batory and Nicole Lindstrom, "The Power of the Purse: Supranational Entrepreneurship, Financial Incentives, and European Higher Education Policy," Governance 24, no. 2 (April 2011): 311-29, https://doi.org/10.1111/j.1468-0491.2011.01525.x. 
higher education as a focus area, are adopted by heads of states. ${ }^{73,74}$ This topdown approach, however, runs the risk of creating a contrived process. The direct involvement of higher education institutions in the whole process, than just implementation, can not be over emphasized.

Some of the differences observed, however, originate from the shortcomings in the African harmonization process. The lack of clear targets and coherent process, the paucity of knowledge and information, are some of the examples. These need to be addressed immediately for the efforts to be effective. All in all, the AU as a continental body in charge of the design and implementation of higher education harmonization, needs to rethink the process towards clearly articluated long term goals, and a roadmap to a (thematically and regionally) coordinated process, that involve higher education institutions and other stakeholders.

Finally, it is imperative to note that comparing harmonization processes in Europe and Africa has its caveats. One needs to be cautious to acknowledge that the two processes do not start at a level field due to inherently considerable differences in resources, infrastructure, the engangement of academics. Besides, in Europe higher education has centuries old history of continued development resulting in well established academic culture and well positioned professional and academic entities, which is not necessarily the same in Africa.

\section{Bibliography}

African Union. "African Union Heads of State and Government Adopts the Continental Education Strategy for Africa (CESA 2016-2025) As the Framework for Transformative Education and Training System," 2016. http://www.au.int/ en/pressreleases/19702/african-union-heads-state-and-government-adoptscontinental-education-strategy.

- "Second Decade of Education for Africa (2006-2015): Draft Plan of Action," 2006. http://www.adea-comed.org/version2/IMG/pdf/SECOND_ DECADE_OF_EDUCATION_FOR.pdf.

African Union, and European Union. "The Africa-EU Strategic Partnership: A Joint Africa-EU Strategy,” 2007. http://www.africa-eu-partnership.org/sites/default/ files/documents/eas2007_joint_strategy_en.pdf.

73 African Union, "Second Decade of Education."

74 African Union, "African Union Heads of State and Government Adopts the Continental Education Strategy for Africa (CESA 2016-2025) As the Framework for Transformative Education and Training System," 2016, http://www.au.int/en/pressreleases/19702/africanunion-heads-state-and-government-adopts-continental-education-strategy. 
. "Joint Africa EU Strategy Action Plan 2011-2013," 2011. http://www. africa-eu-partnership.org/sites/default/files/documents/03-jeas_action_plan_ en.pdf.

—. "Fourth EU-AFRICA Summit: Roadmap 2014-2017," 2014. https://www. consilium.europa.eu/media/21520/142094.pdf.

Babarinde, Olufemi. "The EU as a Model for the African Union: The Limits of Imitation." The Jean Monnet/Robert Schuman Paper Series 7, no. 2 (2007). http://aei.pitt.edu/8185/1/BabarindeEUasModellong07edi.pdf.

Batory, Agnes, and Nicole Lindstrom. "The Power of the Purse: Supranational Entrepreneurship, Financial Incentives, and European Higher Education Policy." Governance 24, no. 2 (April 2011): 311-29. https://doi.org/10.1111/j.1468-0491. 2011.01525.x.

Bennett, Colin J. "What Is Policy Convergence and What Causes It?" British Journal of Political Science 21, no. 2 (1991): 215-33.

Bologna Declaration. "The Bologna Declaration of 19 June 1999. Joint Declaration of the European Ministers of Education," 1999. http://media.ehea.info/file/ Ministerial_conferences/02/8/1999_Bologna_Declaration_English_553028.pdf.

Cini, Michael. "Intergovernmentalism." In European Union Politics, edited by Michael Cini, 93-108. Oxford: Oxford University Press, 2003.

Crosier, David, and Teodora Parveva. The Bologna Process: Its Impact in Europe and beyond. Paris: UNESCO: International Institute for Educational Planning, 2013.

De Wit, Hans. "European Integration in Higher Education: The Bologna Process Towards a European Higher Education Area." In International Handbook of Higher Education, edited by J.J.F. Forest and P.G. Altbach, 461-82. Dordrecht: Springer, 2007.

DiMaggio, Paul J., and Walter W. Powell. "The Iron Cage Revisited: Institutional Isomorphism and Collective Rationality in Organizational Fields." American Sociological Review 48, no. 2 (1983): 147-60. https://doi.org/10.1016/S07423322(00)17011-1.

Dolowitz, David, and David Marsh. "Who Learns What from Whom: A Review of the Policy Transfer Literature." Political Studies 44, no. 2 (June 29, 1996): 343 57. https://doi.org/10.1111/j.1467-9248.1996.tb00334.x.

Dolowitz, David P., and David Marsh. "Learning from Abroad: The Role of Policy Transfer in Contemporary Policy-Making." Governance 13, no. 1 (January 2000): 5-23. https://doi.org/10.1111/0952-1895.00121.

Drezner, Daniel W. "Globalization and Policy Convergence.” International Studies Review 3, no. 1 (2001): 53-78. https://doi.org/10.1111/1521-9488.00225.

European Higher Education Area [EHEA]. "Members - European Higher Education Area and Bologna Process," 2017. https://www .ehea.info/pid34250/members.html. Hahn, Karola, and Damtew Teferra. "Tuning as Instrument of Systematic Higher Education Reform and Quality Enhancement : The African Experience.” Tuning Journal for Higher Education 1, no. 1 (2013): 127-63. http://www.tuningjournal. org/public/site/01/7_Tuning_as_Instrument_of_Systematic_Higher_ Education_Reform_and_Quality_Enhancement.pdf. 
Heyneman, Stephen P. "The History and Problems in the Making of Education Policy at the World Bank, 1960-2000." International Journal of Educational Development 23, no. 3 (2003): 315-37. https://doi.org/10.1016/S1479-3679(04)06002-5.

Lulat, Y. G. M. "The Development of Higher Education in Africa: A Historical Survey." In African Higher Education: An International Reference Handbook, edited by Damtew Teferra and Philip G. Altbach, 15-31. Bloomington: Indiana University Press, 2003.

Marginson, S., and G. Rhoades. "Beyond National States, Markets and Systems of Higher... - Google Scholar." Higher Education 43, no. 3 (2002): 281-309. https://scholar.google.com/scholar?hl=en\&as_sdt=0\%2C22\&q=Beyond+nation al+states $\% 2 \mathrm{C}+$ markets+and+systems+of+higher+education $\% 3 \mathrm{~A}+\mathrm{A}+\mathrm{glonacal}+$ Agency+Heuristic\&btnG $=$.

Meyer, J. W., Frank, D. J., Hironaka, A., Schofer, E., \& Tuma, N. B. “The Structuring of a World Environmental Regime, 1870-1990." International Organization 51, no. 4 (1997): 623-51.https://scholar.google.com/scholar?hl=en\&as_sdt=0\%2C2 $2 \& q=$ The $\% 21+$ structuring $\% 21+$ of $\% 21+a \% 21$ world $\% 21+$ environmental $\% 21+\mathrm{r}$ egime\&btnG $=$.

Mohamedbhai, Goolam. "Towards an African Higher Education and Research Space (AHERS) - A Summary Report,” 2013. http://www.adeanet.org/en/system/files/ resources/ahers_summary_report.pdf.

Neave, Guy. "The Bologna Declaration: Some of the Historic Dilemmas Posed by the Reconstruction of the Community in Europe's Systems of Higher Education." Educational Policy 17, no. 1 (January 25, 2003): 141-64. https://doi.org/ 10.1177/0895904802239290.

Nienhüser, Werner. "Resource Dependence Theory - How Well Does It Explain Behavior of Organizations?" Management Review 19, no. 1\&2 (2008): 9-32. https://doi.org/10.5771/0935-9915-2017-2-192.

Onana, Charles Awono, Olusola Bandele Oyewole, Damtew Teferra, Pablo Beneitone, Julia González, and Robert Wagenaar. Tuning and Harmonisation of Higher Education: The African Experience. Bilbao: University of Deusto, 2014.

Oyewole, Olusola. "The African Quality Rating Mechanisms: The Process, Prospects, and Risks." In Fourth International Conference on Quality Assurance in Higher Education in Africa and Capacity Building. Bamako, 2010. http://ifgu.auf.org/ media/document/KEYNOTE_Oye_AQRM_Process-Prospect_and_Risks_2. pdf.

Sall, Hamidou Nacuzon, and Baye Daraw Ndjaye. "Higher Education in Africa: Between Perspectives Opened by the Bologna Process and the Commodification of Education." European Education 39, no. 4 (2007): 43-57. https://doi. org/10.2753/EUE1056-4934390403.

Samoff, Joel, and Bidemi Carrol. "The Promise of Partnership and Continuities of Dependence: External Support to Higher Education in Africa." African Studies Review 47, no. 1 (2004): 67-199. https://scholar.google.com/scholar?hl=en\&as_ $\mathrm{sdt}=0 \% 2 \mathrm{C} 22 \& \mathrm{q}=\mathrm{The}+$ Promise + of + Partnership+and+Continuities + of + Depend ence\%3A+External+Support+to+Higher+Education+in+Africa+\&btnG=. 
Sehoole, Chika, and Hans de Wit. "The Regionalisation, Internationalisation, and Globalisation of African Higher Education." International Journal of African Higher Education 1, no. 1 (2014): 217-41. https://doi.org/http://dx.doi. org/10.6017/ijahe.v1i1.5648.

Sesay, Amadu. "The African Union: Forward March or About Face-Turn?" Claude Ake Memorial Papers, 2008. http://nai diva-portal.org/smash/get/diva2:278874/ FULLTEXT01.pdf

Sorbonne Declaration. "Sorbonne Joint Declaration. Joint Declaration on Harmonization of the Architecture of The European Higher Education System," 1998. http://media.ehea.info/file/1998_Sorbonne/61/2/1998_Sorbonne_ Declaration_English_552612.pdf.

Vaira, Massimiliano. "Globalization and Higher Education Organizational Change: A Framework for Analysis.” Higher Education 48, no. 4 (2004): 483-510.

Watson, Pam. "Regional Themes and Global Means in Supra-National Higher Education Policy." Higher Education 58, no. 3 (2009): 419-38. https://doi. org/10.1007/s10734-009-9203-3.

Woldegiorgis, Emnet Tadesse. "Conceptualizing Harmonization of Higher Education Systems : The Application of Regional Integration Theories on Higher Education Studies." Higher Education Studies 3, no. 2 (2013): 12-23. https://doi. org/10.5539/hes.v3n2p12.

—. "Historical and Political Perspectives: On Regionalization of African Higher Education." In Regionalization of African Higher Education:Progress and Prospects, edited by Jane Knight and Emnet Tadesse Woldegiorgis, 29-46. Rotterdam, Boston, Taipei: Sense Publishers, 2017.

Woldegiorgis, Emnet Tadesse, Petronella Jonck, and Anne Goujon. "Regional Higher Education Reform Initiatives in Africa: A Comparative Analysis with Bologna Process." International Journal of Higher Education 4, no. 1 (2015): 241-53. https://doi.org/10.5430/ijhe.v4n1p241.

Woldegiyorgis, Ayenachew A. "The Indelible Footmarks of the World Bank in the Higher Education of the Developing World : The Case of Ethiopia." International Journal of Research Studies in Education 3, no. 3 (2014): 93-106.

\section{About the author}

AYENACHEW A. WOLDEGIYORGIS (ayenachew@gmail.com) is a research assistant and doctoral student at the Center for International Higher Education (CIHE), Boston College (USA). He has previously served as a faculty member at Addis Ababa University (Ethiopia) and as consultant for the World Bank (Washington, DC). He is also the immediate past managing editor of the International Journal of African Higher Education. His main research interest includes higher education partnerships, internationalization of higher education, higher education and development, scientific diaspora engagement and policy and governance in higher education. 


\title{
Harmonization of higher education in Africa and Europe: Policy convergence at supranational level
}

\author{
Ayenachew Aseffa Woldegiyorgis \\ doi: http://dx.doi.org/10.18543/tjhe-5(2)-2018pp133-157
}

Received: 06.03.2018

Accepted: 04.05.2018

\section{Copyright}

Copyright for this article is retained by the Publisher. It is an Open Access material that is free for full online access, download, storage, distribution, and or reuse in any medium only for noncommercial purposes and in compliance with any applicable copyright legislation, without prior permission from the Publisher or the author(s). In any case, proper acknowledgement of the original publication source must be made and any changes to the original work must be indicated clearly and in a manner that does not suggest the author's and or Publisher's endorsement whatsoever. Any other use of its content in any medium or format, now known or developed in the future, requires prior written permission of the copyright holder. 